By this process many of Mr. Nasmyth's lunar pictures have been copied, and while on the premises I saw some work then being executed for Mr. Ruskin, and others known in the world of art and science. Bones, and some descriptions of anatomical specimens, are very easily photographed and printed by this process, which is also well adapted for landscapes and architectural subjects. If it be desired, a glaze is given to the finished prints in a very simple way. A little powdered magnesia is sprinkled over the surface of the print, and it is then placed on a smooth board and rubbed with a pad of flannel. Magnesia belongs to the soapstone family, and when used in this way it very readily gives a surface polish to paper.

WILLIAM H. HARRISON

\section{PARIS NEWS}

GOR some time past the Académie des Inscriptions et Belles Lettres has held no regular sitting, almost all the members being refugees in Versailles or elsewhere. A special commission has been given to $M$. Rénan, one of its most distinguished members, to inspect the ruins of the Parisian monuments which have been destroyed by the Cummunists. M. Rénan, before publishing his last books on religious matters, had been sent to Mesopotamia to do the same work as Mr. Layard. Private letters received from the distinguished commissioner have been read before a group of members of different academical bodies at Versailles, sitting almost in an official capacity as the Academy for Inscriptions and Belles Lettres. It was stated that the Louvre buildings had escaped, and the bulk of artistic works will be saved from the conflagration. But the private Imperial Library in the old building of the Ministry of State has been destroyed. The value of this collection was chiefly historical, a number of the volumes being of special value from the fact of their having been presented to the several Kings and Emperors of France during the last three centuries. There were also some manuscripts of value, and collections of drawings for the study of att in the Museum. It was intended to open it shortly as a special art library for the use of students at the Louvre. The National Library, formed by Richelieu, was not burned down as has been rumoured; the building has entirely escaped. But it appears that steps had been taken by the insurgents to destroy it like the Serapion was at Alexandria when Omar took possession of the city. The Luxembourg buildings and $\mathrm{Mu}-$ seum were saved only by the prompt exertions of the troops, when the insurgents were actually setting fire to them. The Luxembourg holds within its precincts a valuable library, where have been collected parliamentary documents from every nation and of every period. It was said to be the most valuable in the world in this respect. The coilection of pictures is the richest in the world for works of living painters belonging to the French school. Courbet, the member of the Commune, had not been admitted to this, esteemed the highest honour by French artists. The Sorbonne is almost entirely saved, the walls only having been pierced by gun-shot or shells. The collections are most valuable, and very serviceable for students. We have no special news from Sainte Geneviève, a library largely used for law purposes on the Place du Panthéon; but it is supposed that the library is safe, as the insurgents were prevented from exploding it, though an immense quantity of powder had been deposited in the cellars, and it was used as an arsenal during the whole of both sieges. The Institute is safe, although it appears steps had been taken for its destruction. The Mazarine Library close to it is most valuable for works of the $I 7$ th and 18 th century, as well as the library of the Arsenal. But according to every probability this last establishment will be entirely lost, owing to the vicinity of the Grenier d'abondance, a place where an immense number of goods were collected, and which was ignited. A commission of the Academy of Sciences will be issued to study the different processe 5 used by the insurgents for burning the Tuileries, Palais Royal, \&c. Hay, soaked with petroleum, appears to have been very often resorted to, as well as canisters full of the same substance. In some instances petroleum had been poured from outside into the cellars, and an ignited match thrown into the impregnated air. The stories of firemen throwing petroleum from fire-engines are, we are happy to say, unfounded.

\section{DREDGING OF THE GULF STREAM}

WYE are much gratified to learn from Harper's Weekly that preparations are now being made, under the direction of the Superintendent of the Coast Survey, for a very complete and thorough investigation of the deep-sea"bottom, and especially of the channel of the Gulf Stream off the eastern coast of America, with an examination also of the Straits of Magellan and of a part of the Pacific Ocean. A steamer is now being built, which will shortly be launched, with the special object of continuing the deep-sea dredgings which, under the direction of Count Pourtalès, have given the Survey so much reputation.

It is expected that the arrangements will be completed by the end of August, and that the whole matter will be specially in charge of Prof. Agassiz, assisted by Count Pourtalès, whose experience eminently qualifies him for the post.

The plan of operations is, first, to run a line of dredging across the Guilf Stream between New York and Bermuda, and, if necessary, far enough eastward to completely cross the Gulf Stream current. The course will be thence to Trinidad, where a careful examination will be entered into to ascertain whether there is any difference in the deep-sea fauna of the adjacent waters and that of the coast of Florida. The expedition will then probably proceed to San Paulo for the purpose of examining the deepest known portion of the Atlantic, reaching to, at least, five thousand fathoms. From San Paulo it will again cut across the Brazilian current, and after possibly spending some time on the coast between Buenos Ayre; and the Straits of Magellan will proceed by a zigzag course to the Falkland Islands, in the neighbourhood of which the expedition will remain for some time, for the purpose of solving certain important problems relating to both the deep-sea fauna and to that of the coast. It is next proposed to spend, at least, a month in the Straits of Magellan during the summer season of that portion of the globe. The work at the Straits being completed, the party expect to pass up along the western coast of Chili, next to the island of Juan Fernandez, and thence across to Callao. From this point the course will be to the Gallapagos, and thence across the Chilian current to some point on the west coast of Mexico-possibly to Mazatlan. The Revillagigedo Islands will next be visited, whence the party will proceed to San Francisco.

The entire exploration will probably occupy ten months, and bids fair to be the most important attempt ever made at determining the character of the fauna of the deep seas. The experience gained in all the former American and foreign expeditions of this kind will be freely used on this occasion; and no pains will be spared in the way of outfit to render the whole undertaking an entire success.

The fact that this expedition is under the direction of the Coast Survey is sufficient guarantee that nothing will be neglected to secure satisfactory results in the way of investigations upon the physics of the ocean, as well as its natural history, as it is intended to make use of the most approved apparatus for the determination of depths, temperatures, specific gravity, and chemical composition of the waters, \&c. 